\title{
Equiliteral Triangle
}

\section{Robert Dawson $\odot$}

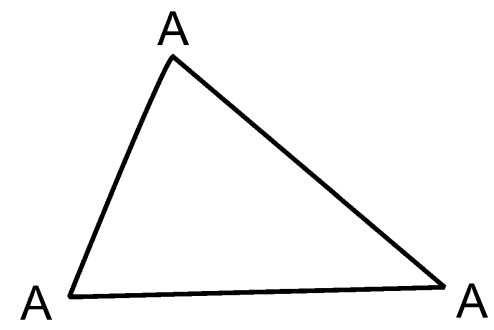

Equiliteral triangle
Department of Mathematics \& Computer Science

St. Mary's University

Halifax, NS B3H 3C3

Canada

e-mail: rdawson@cs.stmarys.ca 